\title{
Effect of Cow Urine and Plant Growth Promoting Rhizobacteria (PGPR) on Seed Germination, Growth and Survival of Karonda (Carissa carandas L.) Seedlings
}

\author{
Shreesty Pal*, T.R. Sharma, and O. P. Nagar \\ Department of Horticulture, College of Agriculture JNKVV, Jabalpur - 482004, (MP), India \\ *Corresponding author
}

\begin{tabular}{|l|}
\hline K e y w o r d s \\
Karonda (Carissa \\
carandas L.), Cow \\
urine, Plant growth \\
promoting \\
rhizobacteria, \\
Pseudomonas
\end{tabular}

\section{A B S T R A C T}

The present investigation entitled "Effect of cow urine and Plant Growth Promoting Rhizobacteria (PGPR) on seed germination, growth and survival of Karonda (Carissa carandas L.) seedlings" was conducted at Fruit Research Station, Imalia, Department of Horticulture, College of Agriculture, J.N.K.V.V., Jabalpur (M.P.) during the year 2018 2019. The experiment was laid out in Factorial Randomized Block Design with three replications. The experiment consist of 8 treatments T0 (Control), T1 (25\% cow urine), T2 (50\% cow urine), T3 (100\% cow urine), T4 (Pseudomonas 6ml/kg seeds), T5 (25\% cow urine + Pseudomonas $6 \mathrm{ml} / \mathrm{kg}$ seeds), T6 (50\% cow urine + Pseudomonas $6 \mathrm{ml} / \mathrm{kg}$ seeds), T7 (100\% cow urine + Pseudomonas $6 \mathrm{ml} / \mathrm{kg}$ seeds). All the seed and soil inoculation treatments showed better germination, growth and survival when compared to uninoculated control. Among various combinations, the combined effect of seed treatment with $25 \%$ cow urine and soil inoculation with $6 \mathrm{ml} / \mathrm{kg}$ pseudomonas were more superior over the other combinations with highest seed germination (5.33 days), 50\% germination (14.50 days), germination at 60 DAS (79.63\%), coefficient of germination (6.10), speed of germination (9.15). Growth parameters at 60, 90 and 120 DAS with seedling height (8.75, 11.20 and $12.60 \mathrm{~cm})$, stem girth $(1.98,2.36$ and $2.64 \mathrm{~mm})$, number of leaves per seedling $(29.3,72.2$ and 89.4) respectively, other growth parameters at 120 DAS such as length of seedling $(28.39 \mathrm{~cm})$, number of roots per seedling (118.3), fresh weight of seedlings (3.41g), dry weight of seedlings $(1.43 \mathrm{~g})$, seedling vigor index I $(2269.7 \mathrm{~cm})$, seedling vigor index II (106.8g), survival of seedlings (81.4\%), leaf area index (4.09), leaf area duration $\left(677798 \mathrm{~cm}^{2}\right.$.days), light transmission ratio $(34.52 \%)$ and energy interception $(0.44 \mathrm{cal}$ $\left.\mathrm{cm}^{-2} \min ^{-1}\right)$.

\section{Introduction}

Carissa carandas is native plant of India while 30 species of genus Carissa have been reported by Singh et al., (1967). It is cultivated throughout India in tropical and subtropical areas. The plants of Carissa are found in plains and hills and wild form in Deccan - Peninsula as well as in West Coast, Punjab, Kashmir, U.P., Mount Abu (Rajasthan), parts of Gujarat and West Bengal (Rai and Gupta, 1996). Karonda is a fruit of 
dry areas and flourishes well on lands with high temperature. At present, it is grown on a limited scale in Rajasthan, Gujarat, Bihar and Uttar Pradesh. It is also grown in other countries viz. Bangladesh, South Africa, U.S.A., Denmark, Ghana, Israel, Pakistan, Nepal and Afghanistan. It is also found in some parts of Sri Lanka in the lowland rain forests eco-region. Karonda fruit is a rich source of iron $\left(3.91^{\circ}\right.$ per on dry weight basis) and contains a fair amount of Vitamin $\mathrm{C}$. Therefore, it is very useful for cure of anemia and has antiscorbutic properties. Vitamin A content of fruit is 1619 IU $100 \mathrm{~g}^{-1}$ of edible portion as well as 87 to 90 per cent pulp, 13 to 14 per cent total soluble solids and 4 to 6 per cent acidity. Under the changing world trade scenario, it can be exploited on a commercial scale as a fruit for the processing industries.

Since, Karonda is very hardy and drought tolerant fruit crop but heavy rainfall and water logged conditions are not desirable. The roots of the plant are heavily branched and make it suitable for stabilizing eroding slopes. It can be grown on a wide range of soils including saline and sodic soils. Propagation by seed is the common method by which plant reproduces in nature and one of the most efficient and widely used propagation methods for raising seedling. Sowing of seed is the physical beginning of seedling propagation. Specific physical and chemical changes that take place during maturation and ripening of the fruit lead to fruit senescence and dissemination of the seed. One of the most obvious changes is the drying of the pericarp tissues. In certain species, this lead to dehiscence and the discharge of the seeds from the fruit. Seeds of most species dehydrate at ripening and prior to dissemination, when moisture content drop to 30 per cent or less. The seed dries further during harvest, usually to about 4-6 per cent for storage. Germination cannot take place at this level of dryness which is important basis for maintaining viability and controlling germination. In certain species, seed must not dry below which 30 to 50 per cent or they will lose their ability to germinate (Chin 1981). Plant species can be separate as recalcitrant or orthodox seed based on their genetic potential to tolerate storage. Most recalcitrant seed cannot tolerate moisture below 25 per cent and some species are also sensitive to chilling temperature. Karonda is commonly propagated by seed and fresh seeds are sown for raising seedlings in the month of August and September. Cow urine contains iron, urea, uric acid, estrogen and progesterone which affect the inhibitory response to seed germination, shoot growth and seedling vigor (Dilrukshi, 2009). Plant growth promoting rhizobacteria are the soil bacteria inhabiting around and, on the surface and are directly or indirectly involved in promoting plant growth and development via production and secretion of various regulatory chemicals in the vicinity of rhizosphere. They stimulate plant growth through mobilizing nutrients in soils, producing numerous plant growth regulators, protecting plants from phytopathogens by controlling or inhibiting them, improving soil structure and bioremediating the polluted soils by sequestering toxic heavy metal species and degrading xenobiotic compounds (like pesticides) (Ahemad, 2012; Hayat et al., 2010; Rajkumar et al., 2010; Braud et al., 2009).

\section{Materials and Methods}

\section{Experimental site}

The experiment was conducted at Fruit Research Station, Imalia, Department of Horticulture, College of Agriculture, J.N.K.V.V., Jabalpur, Madhya Pradesh, India. The experiment was conducted during October 2018 to February 2019. The experimental site was situated at $23.9^{\circ} \mathrm{N}$ latitude and $79.58^{\circ} \mathrm{E}$ longitude and an altitude of 411.78 meters above Mean Sea Level (MSL). 


\section{Seed materials}

The seeds of Karonda (Carissa carandas L.) were obtained from Fruit Research Station of Jawaharlal Nehru Krishi Vishwa Vidyalaya, Imalia, Jabalpur District, Madhya Pradesh, India.

\section{Plant Growth Promoting Rhizobacteria}

Plant growth promoting rhizobacteria (Pseudomonas) was obtained from the Department of Soil Microbiology, Faculty of Agriculture, JNKVV, Jabalpur, Madhya Pradesh.

\section{Preparation of seed soaking media}

$25 \mathrm{ml}$ and $50 \mathrm{ml}$ fresh cow urine was measured with measuring cylinder and poured into $100 \mathrm{ml}$ beaker each.

The volume was made up by addition of distilled water to prepare 25 per cent and 50 per cent solution of cow urine respectively. $100 \mathrm{ml}$ fresh cow urine in $100 \mathrm{ml}$ beaker gave 100 per cent solution of cow urine.

\section{Seed Treatment}

Freshly harvested seeds of Karonda were soaked in cow urine solutions of different concentrations $(25 \%, 50 \%$ and $100 \%)$ for a period of 24 hours and sown in polybags under the poly house.

\section{Soil Inoculation}

Pseudomonas solution was measured with measuring cylinder and applied to soil @ $6 \mathrm{ml}$ per kg.

\section{Filling of polybags}

Polybags of 200 gauge thickness having length of $15 \mathrm{~cm}$ and diameter of $10 \mathrm{~cm}$ were used. Bags were filled as per treatment i.e. with and without pseudomonas.

\section{Seed sowing}

Treated seeds of Karonda were sown in polythene bags of $15 \times 10 \mathrm{~cm}$ size filled with and without Pseudomonas treated soil.

One seed per poly bag was sown at $2-2.5 \mathrm{~cm}$ depth.

\section{Seed vigor parameters}

\section{Initiation of germination}

The days taken to initiate germination in each treatment after sowing were observed and recorded.

\section{$\mathbf{5 0 \%}$ germination}

The days taken for 50 per cent germination in each treatment after sowing were observed and recorded.

\section{Germination at 60 days after sowing (\%)}

The germination in each treatment was recorded at 60 days after sowing. Number of germinated seeds were counted and expressed as germination percentage.

\section{Coefficient of germination}

The germination in each treatment was recorded after sowing. Number of seedlings was counted and expressed the coefficient of germination.

\section{Speed of germination}

When seeds started germinating their number was counted daily till maximum germination was obtained. 


\section{Growth parameters}

\section{Seedling height}

Five plants were randomly selected for recording the shoot length of seedlings. They were measured by using centimeter scale and recorded at 60,90 and 120 DAS.

\section{Stem girth (mm)}

The diameter of shoot above the root collar region was recorded using Vernier caliper at 60, 90 and 120 days after sowing for five randomly selected tagged plants in each treatment and the average of girth was computed.

\section{Number of leaves per seedling}

The total number of leaves was counted from five randomly selected plants in each treatment at 60,90 and 120 days after sowing and the average of number of leaves was computed.

\section{Length of seedling (cm)}

The height of seedling is measured from root tip to the shoot tip and expressed in centimeter at 120 days after sowing.

\section{Number of roots per seedling}

The number of roots per seedling, primary, secondary and tertiary and rootlets were counted.

\section{Fresh weight of seedling (g)}

The plants were carefully washed to remove the soil adhering to their roots and shoots. The weight was taken with the help of electronic balance and average value was computed.

\section{Dry weight of seedling (g)}

For dry weight plants were chopped and oven dried at $60 \pm 20^{\circ} \mathrm{C}$ temperature till a constant weight. The weight was taken with the help of electronic balance and average value was computed.

\section{Seedling vigor index - I (cm)}

It was calculated by adding the values of root length and shoot length which was randomly selected and multiplying with their corresponding germination per cent and the values were recorded.

Seedling vigor index $\mathrm{I}=$ germination per cent $x$ [root length $(\mathrm{cm})+$ shoot length $(\mathrm{cm})]$

\section{Seedling vigor index - II (g)}

It was calculated by multiplying dry weight of seedlings with their corresponding germination per cent.

Seedling vigor index II = dry weight of seedlings (g) x germination per cent

\section{Survival percentage of seedlings}

The survival percentage of each treatment was recorded at 120 days after seed sowing.

\section{Physiological parameters}

\section{Leaf Area Index}

LAI expresses the ratio of leaf surface considerably to the ground area occupied by the plant or a crop stand worked out as per specification of Gardner et al., (1985)

\section{Leaf Area Duration (LAD) (cm².days)}

Leaf Area Duration expresses the magnitude and persistence of leaf area of leafiness during 
the period of crop growth. It reflects the extent of period of crop growth. It reflects the extent of seasonal integral of light interaction and corrected with yield.

\section{Light Transmission Ratio (LTR) (\%)}

It was given by Golingai and Mabbayad in 1969.

\section{Energy Interception (EI) (cal $\left.\mathrm{cm}^{-2} \mathrm{~min}^{-1}\right)$}

It can be calculated by lux meter. Its values were converted in terms of energy as per constants. The values were recorded at 90 and 120 DAS and then the mean value was worked out.

$71 \mathrm{~K} \mathrm{Lux}=1$ calorie per $\mathrm{cm}^{2}$ per $\min$

$\mathrm{EI}=$ total incident energy - transmitted energy

\section{Results and Discussion}

\section{Seed vigor parameters}

\section{Initiation of germination}

The results on the effect of cow urine and Plant Growth Promoting Rhizobacteria on initiation of germination of Karonda seeds is shown in Table 1. Earliest germination (5.33 days) was recorded in seeds treated with $25 \%$ cow urine and sown in soil inoculated with pseudomonas $6 \mathrm{ml} / \mathrm{kg}$. Soaking of tamarind seeds in 10per cent cow urine or cow dung solution for $24 \mathrm{~h}$ increased the germination and vigor index as compared to that of untreated seeds (Shankaranarayanan et al., 1994). Inoculation of seeds of Phragmites australis with Pseudomonas asplenii improved germination (Bashan et al., 2008)

\section{$50 \%$ germination}

The results on the effect of cow urine and Plant Growth Promoting Rhizobacteria on initiation of germination of Karonda seeds is shown in Table 1. Minimum days taken to $50 \%$ germination (14.50) was recorded in seeds treated with $25 \%$ cow urine and sown in soil inoculated with pseudomonas $6 \mathrm{ml} / \mathrm{kg} .10$ per cent cow urine 24 hours soaking treatment is effective for breaking dormancy and increasing germination and seedling growth tamarind (Parameswari et al., 2001).

Plant Growth Promoting Rhizobacteria significantly enhanced seed germination and seedling vigor of maize (Gholami et al., 2009).

\section{Germination at 60 DAS (\%)}

The results regarding the effect of cow urine and Plant Growth Promoting Rhizobacteria on germination percentage at 60 days after sowing of Karonda seedlings is represented in Table 1.

The highest percentage of germination $(79.63 \%)$ was recorded in seeds treated with $25 \%$ cow urine and sown in soil inoculated with pseudomonas $6 \mathrm{ml} / \mathrm{kg}$. Khirni seeds soaked in 20 per cent cow urine was effective to get early and maximum germination per cent (Shinde et al., 2015).

\section{Coefficient of germination}

The results regarding the effect of cow urine and Plant Growth Promoting Rhizobacteria on coefficient of germination of Karonda seedlings is represented in Table 1.

The highest coefficient of germination (6.10) was recorded in seeds treated with $25 \%$ cow urine and sown in soil inoculated with pseudomonas $6 \mathrm{ml} / \mathrm{kg}$. Sweet flag seed treated with mixture of $50 \mathrm{~g}$ of powdered rhizomes 2.5 I of water 1 I of cow urine showed germination high, seedling growth fast and also increasing tolerance against insect pest (Vijayalakshmi et al., 1998). 


\section{Speed of germination}

The results on the effect of cow urine and Plant Growth Promoting Rhizobacteria on speed of germination of Karonda seeds is shown in Table 1. The highest speed of germination (9.15) was recorded in seeds treated with $25 \%$ cow urine and sown in soil inoculated with pseudomonas $6 \mathrm{ml} / \mathrm{kg}$.

\section{Growth Parameters}

\section{Seedling height $(\mathrm{cm})$}

The results on the effect of cow urine and Plant Growth Promoting Rhizobacteria on seedling height at various intervals $(60,90$ and 120 DAS) is represented in Table 2. The maximum seedling height $(8.75,11.20$ and $12.60 \mathrm{~cm}$ ) was obtained in seeds treated with $25 \%$ cow urine and sown in soil inoculated with pseudomonas $6 \mathrm{ml} / \mathrm{kg}$. There is increase $\mathrm{P}$ uptake, biomass and yield of gram due to seed treatment with Pseudomonas striata (Krishna Murthy et al., 1991)

\section{Stem girth $(\mathbf{m m})$}

The results on the effect of cow urine and Plant Growth Promoting Rhizobacteria on stem girth at various intervals $(60,90$ and 120 DAS) is represented in Table 2. The maximum stem girth $(1.98,2.36$ and $2.64 \mathrm{~mm})$ was obtained in seeds treated with $25 \%$ cow urine and sown in soil inoculated with pseudomonas $6 \mathrm{ml} / \mathrm{kg}$.

\section{Number of leaves per seedling}

The results on the effect of cow urine and Plant Growth Promoting Rhizobacteria on number of leaves per seedling at various intervals $(60,90$ and 120 DAS) is represented in Table 2. The maximum number of leaves (29.3, 72.2 and 89.4) were obtained in seeds treated with $25 \%$ cow urine and sown in soil inoculated with pseudomonas $6 \mathrm{ml} / \mathrm{kg}$. seed soaking of custard apple in 10 per cent cow urine for 24 hours increased germination percentage, height of seedling, no of leaves per seedlings, number of roots per length of roots and fresh and dry weight of seedlings (Rao, 1975).

\section{Length of seedling (cm)}

The results regarding the effect of cow urine and Plant Growth Promoting Rhizobacteria on length of seedling of Karonda seeds at 120 DAS is represented in Table 2. The longest seedling $(28.39 \mathrm{~cm})$ was recorded in seeds treated with $25 \%$ cow urine and sown in soil inoculated with pseudomonas $6 \mathrm{ml} / \mathrm{kg}$.

\section{Number of roots per seedling}

The results regarding the effect of cow urine and Plant Growth Promoting Rhizobacteria on number of roots per seedling at 120 days after sowing of Karonda seeds is represented in Table 2. The maximum number of roots per seedling (118.3) was recorded in seeds treated with 25\% cow urine and sown in soil inoculated with pseudomonas $6 \mathrm{ml} / \mathrm{kg}$.

\section{Fresh weight of seedling (g)}

The results regarding the effect of cow urine and Plant Growth Promoting Rhizobacteria on fresh weight of seedlings at 120 days after sowing of Karonda seeds is represented in Table 2. The maximum fresh weight $(3.41 \mathrm{~g})$ was recorded in seeds treated with $25 \%$ cow urine and sown in soil inoculated with pseudomonas $6 \mathrm{ml} / \mathrm{kg}$.

\section{Dry weight of seedlings (g)}

The results regarding the effect of cow urine and Plant Growth Promoting Rhizobacteria on dry weight of seedlings at 120 days after sowing of Karonda seeds is represented in Table 2. 
Table.1 Effect of cow urine and plant growth promoting rhizobacteria (PGPR) on seed vigor and growth parameters

\begin{tabular}{|c|c|c|c|c|c|c|c|c|}
\hline \multirow[t]{2}{*}{ Treatments } & \multirow{2}{*}{$\begin{array}{c}\text { Initiation of } \\
\text { germination (days) }\end{array}$} & \multirow{2}{*}{$\begin{array}{l}50 \% \text { germination } \\
\text { (days) }\end{array}$} & \multirow{2}{*}{$\begin{array}{c}\text { Germination } 60 \\
\text { DAS (\%) }\end{array}$} & \multirow{2}{*}{$\begin{array}{c}\text { Speed of } \\
\text { germination }\end{array}$} & \multirow{2}{*}{$\begin{array}{l}\text { Coefficient of } \\
\text { germination }\end{array}$} & \multicolumn{3}{|c|}{ Seedling height $(\mathbf{c m})$} \\
\hline & & & & & & 60 DAS & 90 DAS & $120 \mathrm{DA}$ \\
\hline $\begin{array}{c}\text { T0 - control (tap } \\
\text { water) }\end{array}$ & 9.83 & 24.50 & 63.10 & 5.10 & 3.95 & 4.91 & 7.35 & 9.36 \\
\hline $\mathrm{T} 1-25 \%$ cow urine & 7.83 & 18.33 & 70.68 & 6.51 & 4.63 & 6.74 & 9.02 & 11.09 \\
\hline $\mathrm{T} 2-50 \%$ cow urine & 8.50 & 19.00 & 70.15 & 6.43 & 4.60 & 6.70 & 9.10 & 10.55 \\
\hline T3 - 100\% cow urine & 8.50 & 19.38 & 69.56 & 6.01 & 4.50 & 6.42 & 8.74 & 10.51 \\
\hline $\begin{array}{c}\mathrm{T} 4-\text { Pseudomonas } \\
6 \mathrm{ml} / \mathrm{kg}\end{array}$ & 9.00 & 22.83 & 65.18 & 5.61 & 4.30 & 6.16 & 8.07 & 9.95 \\
\hline $\begin{array}{l}\mathrm{T} 5-25 \% \text { cow urine } \\
+ \text { Pseudomonas } \\
6 \mathrm{ml} / \mathrm{kg}\end{array}$ & 5.33 & 14.50 & 79.63 & 9.15 & 6.10 & 8.75 & 11.20 & 12.60 \\
\hline $\begin{array}{c}\text { T6 - 50\% cow urine } \\
+ \text { Pseudomonas } \\
6 \mathrm{ml} / \mathrm{kg}\end{array}$ & 6.33 & 15.00 & 78.71 & 8.80 & 5.55 & 7.85 & 10.23 & 11.70 \\
\hline $\begin{array}{c}\mathrm{T} 7-100 \% \text { cow urine } \\
+ \text { Pseudomonas } \\
6 \mathrm{ml} / \mathrm{kg}\end{array}$ & 6.33 & 15.50 & 72.91 & 8.23 & 5.35 & 7.60 & 9.78 & 11.65 \\
\hline SEm \pm & 0.15 & 0.20 & 0.24 & 0.02 & 0.019 & 0.040 & 0.056 & 0.091 \\
\hline CD at $5 \%$ level & 0.44 & 0.59 & 0.71 & 0.07 & 0.055 & 0.115 & 0.162 & 0.263 \\
\hline
\end{tabular}


Table.2 Effect of cow urine and plant growth promoting rhizobacteria (PGPR) on growth parameters at different intervals

\begin{tabular}{|c|c|c|c|c|c|c|c|c|c|c|c|c|}
\hline \multirow[t]{2}{*}{ Treatments } & \multicolumn{3}{|c|}{ Stem girth (mm) } & \multicolumn{3}{|c|}{ Number of leaves per seedling } & \multirow{2}{*}{$\begin{array}{l}\text { Length of } \\
\text { seedling at } \\
120 \text { DAS } \\
\text { (cm) }\end{array}$} & \multirow{2}{*}{$\begin{array}{l}\text { Number of } \\
\text { roots per } \\
\text { seedling at } \\
120 \text { DAS }\end{array}$} & \multirow{2}{*}{$\begin{array}{c}\text { Fresh weight } \\
\text { of } \\
\text { shoots at } \\
120 \text { DAS (g) }\end{array}$} & \multirow{2}{*}{$\begin{array}{l}\text { Dry weight } \\
\text { of shoots at } \\
120 \text { DAS (g) }\end{array}$} & \multirow{2}{*}{$\begin{array}{l}\text { Fresh weight } \\
\text { of } \\
\text { roots at } 120 \\
\text { DAS (g) }\end{array}$} & \multirow{2}{*}{$\begin{array}{c}\text { Dry weight } \\
\text { of roots at } \\
120 \text { DAS } \\
\text { (g) }\end{array}$} \\
\hline & 60 DAS & 90 DAS & 120 DAS & $\begin{array}{c}\text { 60 } \\
\text { DAS }\end{array}$ & $\begin{array}{c}90 \\
\text { DAS }\end{array}$ & $\begin{array}{l}120 \\
\text { DAS }\end{array}$ & & & & & & \\
\hline $\begin{array}{c}\text { T0 - control } \\
(\text { tap water })\end{array}$ & 1.42 & 1.86 & 2.13 & 13.13 & 32.06 & 49.36 & 19.42 & 40.23 & 1.11 & 0.35 & 0.35 & 0.14 \\
\hline $\mathrm{T} 1-25 \%$ cow urine & 1.78 & 2.07 & 2.28 & 21.73 & 46.43 & 57.50 & 21.92 & 70.41 & 1.99 & 0.68 & 0.50 & 0.20 \\
\hline $\mathrm{T} 2-50 \%$ cow urine & 1.74 & 2.00 & 2.25 & 21.03 & 45.30 & 57.90 & 20.90 & 63.63 & 1.87 & 0.65 & 0.47 & 0.18 \\
\hline $\begin{array}{c}\mathrm{T} 3-100 \% \text { cow } \\
\text { urine }\end{array}$ & 1.73 & 1.99 & 2.24 & 20.70 & 44.60 & 56.50 & 20.44 & 55.76 & 1.76 & 0.59 & 0.46 & 0.18 \\
\hline $\begin{array}{c}\mathrm{T} 4-\text { pseudomonas } \\
6 \mathrm{ml} / \mathrm{kg}\end{array}$ & 1.65 & 1.92 & 2.15 & 19.26 & 40.73 & 50.93 & 19.97 & 46.80 & 1.32 & 0.43 & 0.38 & 0.15 \\
\hline $\begin{array}{c}\text { T5 - 25\% cow urine } \\
+ \text { pseudomonas } \\
6 \mathrm{ml} / \mathrm{kg}\end{array}$ & 1.98 & 2.36 & 2.64 & 29.33 & 72.20 & 89.43 & 28.39 & 118.38 & 2.63 & 1.09 & 0.78 & 0.34 \\
\hline $\begin{array}{c}\text { T6 - 50\% cow urine } \\
+ \text { pseudomonas } \\
6 \mathrm{ml} / \mathrm{kg}\end{array}$ & 1.91 & 2.28 & 2.50 & 28.10 & 68.70 & 78.00 & 27.23 & 115.23 & 2.50 & 0.86 & 0.70 & 0.26 \\
\hline $\begin{array}{c}\mathrm{T} 7-100 \% \text { cow } \\
\text { urine }+ \\
\text { pseudomonas } \\
6 \mathrm{ml} / \mathrm{kg}\end{array}$ & 1.88 & 2.24 & 2.44 & 24.03 & 62.60 & 73.76 & 25.67 & 101.83 & 2.40 & 0.82 & 0.59 & 0.24 \\
\hline SEm \pm & 0.007 & 0.003 & 0.006 & 0.291 & 0.755 & 0.458 & 0.17 & 1.18 & 0.03 & 0.04 & 0.001 & 0.003 \\
\hline CD at $5 \%$ level & 0.021 & 0.009 & 0.017 & 0.841 & 2.182 & 1.324 & 0.50 & 3.41 & 0.11 & 0.11 & 0.002 & 0.008 \\
\hline
\end{tabular}


Table.3 Effect of cow urine and plant growth promoting rhizobacteria (PGPR) on growth and physiological parameters at 120 days after sowing

\begin{tabular}{|c|c|c|c|c|c|c|c|}
\hline Treatments & $\begin{array}{l}\text { Seedling vigor } \\
\text { Index I (cm) }\end{array}$ & $\begin{array}{l}\text { Seedling vigor } \\
\text { index II (g) }\end{array}$ & $\begin{array}{c}\text { Survival of } \\
\text { seedlings }(\%)\end{array}$ & $\begin{array}{l}\text { Leaf Area } \\
\text { Index }\end{array}$ & $\begin{array}{l}\text { Leaf Area } \\
\text { Duration } \\
\left(\mathrm{cm}^{2} \text {.days }\right)\end{array}$ & $\begin{array}{c}\text { Light Transmission } \\
\text { Ratio }(\%)\end{array}$ & $\begin{array}{l}\text { Energy Interception } \\
\quad\left(\mathrm{cal} \mathrm{cm}^{-2} \mathrm{~min}^{-1}\right)\end{array}$ \\
\hline T0 - control (tap water) & 1207.00 & 31.71 & 64.28 & 1.13 & 1611.55 & 81.39 & 0.12 \\
\hline $\mathrm{T} 2-50 \%$ cow urine & 1346.53 & 53.59 & 68.15 & 1.87 & 2974.03 & 59.58 & 0.17 \\
\hline $\mathrm{T} 3-100 \%$ cow urine & 1321.56 & 51.31 & 67.15 & 1.79 & 2814.00 & 61.02 & 0.15 \\
\hline $\begin{array}{c}\text { T4 - Pseudomonas } \\
6 \mathrm{ml} / \mathrm{kg}\end{array}$ & 1250.10 & 38.58 & 65.28 & 1.43 & 2222.03 & 70.91 & 0.12 \\
\hline $\begin{array}{l}\mathrm{T} 5-25 \% \text { cow urine }+ \\
\text { Pseudomonas } 6 \mathrm{ml} / \mathrm{kg}\end{array}$ & 2269.79 & 106.85 & 81.46 & 4.09 & 6777.98 & 34.52 & 0.44 \\
\hline $\begin{array}{l}\text { T6 - 50\% cow urine }+ \\
\text { Pseudomonas } 6 \mathrm{ml} / \mathrm{kg}\end{array}$ & 2121.61 & 88.14 & 80.18 & 2.95 & 4912.13 & 38.66 & 0.36 \\
\hline $\begin{array}{l}\mathrm{T} 7-100 \% \text { cow urine }+ \\
\text { Pseudomonas } 6 \mathrm{ml} / \mathrm{kg}\end{array}$ & 1866.81 & 77.54 & 74.13 & 2.62 & 4327.35 & 39.91 & 0.26 \\
\hline SEm \pm & 21.71 & 0.88 & 0.37 & 0.02 & 41.50 & 0.40 & 0.003 \\
\hline CD at $5 \%$ level & 62.73 & 2.54 & 1.07 & 0.06 & 119.91 & 1.18 & 0.009 \\
\hline
\end{tabular}


The maximum dry weight $(1.43 \mathrm{~g})$ was recorded in seeds treated with $25 \%$ cow urine and sown in soil inoculated with pseudomonas $6 \mathrm{ml} / \mathrm{kg}$.

\section{Seedling vigor index - I $(\mathrm{cm})$}

The results regarding the effect of cow urine and Plant Growth Promoting Rhizobacteria on Seedling vigor index - I at 120 days after sowing of Karonda seeds is represented in Table 3. The maximum seedling vigor index-I $(2269.7 \mathrm{~cm})$ was recorded in seeds treated with $25 \%$ cow urine and sown in soil inoculated with pseudomonas $6 \mathrm{ml} / \mathrm{kg}$.

\section{Seedling vigor index - II (g)}

The results regarding the effect of cow urine and Plant Growth Promoting Rhizobacteria on Seedling vigor index - II at 120 days after sowing of Karonda seeds is represented in Table 3. The maximum seedling vigor indexII (106.8 g) was recorded in seeds treated with $25 \%$ cow urine and sown in soil inoculated with pseudomonas $6 \mathrm{ml} / \mathrm{kg}$.

\section{Survival percentage of seedlings}

The results regarding the effect of cow urine and Plant Growth Promoting Rhizobacteria on survival percentage of seedlings at 120 days after sowing of Karonda seeds is represented in Table 3. The maximum survival $(81.46 \%)$ was recorded in seeds treated with $25 \%$ cow urine and sown in soil inoculated with pseudomonas $6 \mathrm{ml} / \mathrm{kg}$.

\section{Physiological parameters}

\section{Leaf Area Index}

The results regarding the effect of cow urine and Plant Growth Promoting Rhizobacteria on leaf area index at 120 days after sowing of Karonda seedlings is represented in Table 3.
The maximum LAI (4.09) was recorded in seeds treated with $25 \%$ cow urine and sown in soil inoculated with pseudomonas $6 \mathrm{ml} / \mathrm{kg}$. Albizia lebbeck seeds soaked with cow urine showed significant increase in shoot length, root length, total leaf area and total dry weight of seedlings (IIlango et al., 1999).

\section{Leaf Area Duration $\left(\mathrm{cm}^{2}\right.$.days)}

The results regarding the effect of cow urine and Plant Growth Promoting Rhizobacteria on leaf area duration at 120 days after sowing of Karonda seedlings is represented in Table 3. The maximum LAD (677798 $\mathrm{cm}^{2}$.days) was recorded in seeds treated with $25 \%$ cow urine and sown in soil inoculated with pseudomonas $6 \mathrm{ml} / \mathrm{kg}$. Pseudomonas ACC-deaminaseproducing strains can improve the growth, physiology, and quality of mung beans under salt-affected environments (Ahmad 2013)

\section{Light transmission ratio $(\%)$}

The results regarding the effect of cow urine and Plant Growth Promoting Rhizobacteria on light transmission ratio at 120 days after sowing of Karonda seedlings is represented in Table 3. The lowest LTR (34.52\%) was recorded in seeds treated with $25 \%$ cow urine and sown in soil inoculated with pseudomonas $6 \mathrm{ml} / \mathrm{kg}$. Plant Growth Promoting Rhizobacteria enhanced yield and growth of wheat (Ozturk et al., 2003)

\section{Energy interception $\left(\mathrm{cal} \mathrm{cm}^{-2} \mathrm{~min}^{-1}\right.$ )}

The results regarding the effect of cow urine and Plant Growth Promoting Rhizobacteria on energy interception at 120 days after sowing of Karonda seedlings is represented in Table 3. The highest EI $\left(0.44 \mathrm{cal} \mathrm{cm}^{-2} \mathrm{~min}^{-1}\right)$ was recorded in seeds treated with $25 \%$ cow urine and sown in soil inoculated with pseudomonas $6 \mathrm{ml} / \mathrm{kg}$. Increase in seed yield and $\mathrm{N}$ uptake by crop when pigeon pea seeds were 
inoculated with Pseudomanas striata before sowing (Pawar and Pawar, 1998).

\section{Acknowledgement}

The author wish to thank the research guide and Head of the Department and staff of Horticulture, Jawaharlal Nehru Krishi Vishwa Vidyalaya, Jabalpur, Madhya Pradesh for providing necessary facility in conducting the experiment. Special thanks to the family members and friends for their unconditional support.

\section{References}

Ahemad M. 2012. Implications of bacterial resistance against heavy metals in bioremediation: a review. IIOABJ 3, 39-46.

Ahmad M., Z.A. Zahir, M. Khalid, 2013 Efficacy of Rhizobium and Pseudomonas strains to improve physiology, ionic balance and quality of mung bean under salt-affected conditions on farmer's fields. Plant Physiol. Biochem., 63, 170-176.

Bashan Y., M.E. Puente, L.E. de-Bashan, J.P. Hernandez, 2008. Environmental uses of plant growth-promoting bacteria. In: Barka EA, Clement C (eds) Plantmicrobe interactions. Trivandrum, Kerala, India, pp 69-93.

Braud A, Je'ze'quel K, Bazot S, Lebeau T, 2009. Enhanced phytoextraction of an agricultural $\mathrm{Cr}-$, $\mathrm{Hg}-$ and $\mathrm{Pb}-$ contaminated soil by bioaugmentation with siderophore producing bacteria. Chemosphere 74, 280-286.

Chin HF. 1981. Cited in, propagation of tropical and subtropical horticultural crops. ed.

Bose TK, Mitra SK, Sandhu MK, Das P, Sanyal D. and Parthasarathy. V.A. p. 31.Naya Udyog, 206, Bidhan Sarani, Kolkata 662p.

Dilrukshi HNN and Perera ANF. 2009.
Evaluation of an ancient technique to diagnose the pregnancy in cattle using urine. Wayamba Journal of Animal Science 6-8.

Gholami A., S. Shahsavani and S. Nezarat, 2009. The effect of plant growth promoting rhizobacteria (PGPR) on germination, seedling growth an yield of maize. International Journal of Biosystems Engineering 3(1).

Hayat R, Ali S, Amara U, Khalid R, Ahmed I. 2010. Soil beneficial bacteria and their role in plant growth promotion: a review. Ann Microbiol. 60, 579-598.

Illango K., K. Vanangamudi, A. Vanangamudi, R.S. Venkatesh, R.S. Vinayarai and S. Balaji, 1999. Effect of growth stimulants on seed germination and seedling vigour in Albizia lebbeck (L). Benth. Seed Research 27(2): 188-190.

Krishnamurthy H.A., A.R. Alagawadi and P.V. Krishnaraj, 1991. Inhibition of phosphate solubilizing activity of microbes and $\mathrm{P}$ uptake in green plants by fenvelerate. J. Ecobiol., 3: 175 179.

Ozturk A., O. Caglar and F. Sahin, 2003. Yield response of wheat and barley to inoculation of plant growth promoting rhizobacteria at various levels of nitrogen fertilization. J. Plant. Nutr. Soil Sci., vol.166, pp. 262-266.

Parameswari K., P. Srimathi, K. Malarkodi, 2001. Standardization of dormancy breaking treatment in tamarind (Tamarindus indica L.) seed legume Research 24 (1) 60-6.

Pawar P.P. and V.S. Pawar, 1998. Response of pigeon pea CV ICPL -87 to application of phosphorus and $\mathrm{P}$ solubilizers. J. Maharashtra Agricultural University, 23: 126 -128.

Rajkumar M, Ae N, Prasad MNV, Freitas H. 2010. Potential of siderophoreproducing bacteria for improving 
heavy metal phytoextraction. Trends Biotechnol. 28, 142- 149.

Rao S.P., 1975. Effect of seed treatment with cow urine on seed germination and seedling growth of custard apple. Ind. J. of Agr. Res. 9 (3): 121-126.

Sankaranarayana RM, Vijay Kumar and Rangasamy P. 1994. Cow urine ideal seed germination in Tamarinds Indian Hert. J. 38 (4): 15.

Shinde V.V. and K.V. Malshe, 2015. Effect of cattle urine and cow dung slurry as seed treatment on germination and growth of Khirni (Manilkara hexandra L.) J. of Eco-friendly Agriculture 10(2): $128-130$

Singh S, Krishnamurthi S and Katyal S 1967. The karonda. Fruit Culture in India. ICAR, New Delhi, pp 287-288.

Vijayalakshmi KB, Subshashini and Kaul S. 1998. Plant in pest control custard apple vitex, sweet flag and poison nut. CIKS Chennai, India 23.

\section{How to cite this article:}

Shreesty Pal, T.R. Sharma and Nagar, O.P. 2019. Effect of Cow Urine and Plant Growth Promoting Rhizobacteria (PGPR) on Seed Germination, Growth and Survival of Karonda (Carissa carandas L.) Seedlings. Int.J.Curr.Microbiol.App.Sci. 8(11): 1967-1978. doi: https://doi.org/10.20546/ijcmas.2019.811.230 